\title{
Optimization of DNA extraction for advancing coral microbiota investigations
}

Laura Weber ${ }^{1,2}$, Emelia DeForce ${ }^{3}$ and Amy Apprill ${ }^{2^{*}}$ (D)

\begin{abstract}
Background: DNA-based sequencing approaches are commonly used to identify microorganisms and their genes and document trends in microbial community diversity in environmental samples. However, extraction of microbial DNA from complex environmental samples like corals can be technically challenging, and extraction methods may impart biases on microbial community structure.

Methods: We designed a two-phase study in order to propose a comprehensive and efficient method for DNA extraction from microbial cells present in corals and investigate if extraction method influences microbial community composition. During phase I, total DNA was extracted from seven coral species in a replicated experimental design using four different MO BIO Laboratories, Inc., DNA Isolation kits: PowerSoil ${ }^{\oplus}$, PowerPlant ${ }^{\oplus}$ Pro, PowerBiofilm ${ }^{\oplus}$, and UltraClean ${ }^{\oplus}$ Tissue \& Cells (with three homogenization permutations). Technical performance of the treatments was evaluated using DNA yield and amplification efficiency of small subunit ribosomal RNA (SSU ribosomal RNA (rRNA)) genes. During phase II, potential extraction biases were examined via microbial community analysis of SSU rRNA gene sequences amplified from the most successful DNA extraction treatments.

Results: In phase I of the study, the PowerSoil ${ }^{\oplus}$ and PowerPlant ${ }^{\oplus}$ Pro extracts contained low DNA concentrations, amplified poorly, and were not investigated further. Extracts from PowerBiofilm ${ }^{\circledR}$ and UltraClean ${ }^{\oplus}$ Tissue and Cells permutations were further investigated in phase II, and analysis of sequences demonstrated that overall microbial community composition was dictated by coral species and not extraction treatment. Finer pairwise comparisons of sequences obtained from Orbicella faveolata, Orbicella annularis, and Acropora humilis corals revealed subtle differences in community composition between the treatments; PowerBiofilm ${ }^{\oplus}$-associated sequences generally had higher microbial richness and the highest coverage of dominant microbial groups in comparison to the UltraClean ${ }^{\oplus}$ Tissue and Cells treatments, a result likely arising from using a combination of different beads during homogenization.

Conclusions: Both the PowerBiofilm ${ }^{\oplus}$ and UltraClean ${ }^{\oplus}$ Tissue and Cells treatments are appropriate for large-scale analyses of coral microbiota. However, studies interested in detecting cryptic microbial members may benefit from using the PowerBiofilm ${ }^{\oplus}$ DNA treatment because of the likely enhanced lysis efficiency of microbial cells attributed to using a variety of beads during homogenization. Consideration of the methodology involved with microbial DNA extraction is particularly important for studies investigating complex host-associated microbiota.
\end{abstract}

Keywords: Coral microbiota, DNA extraction, Optimization, SSU ribosomal RNA gene, Amplicon sequencing

\footnotetext{
* Correspondence: aapprill@whoi.edu

${ }^{2}$ Woods Hole Oceanographic Institution, Marine Chemistry and

Geochemistry, Woods Hole, MA 02543, USA

Full list of author information is available at the end of the article
} 


\section{Background}

The coral holobiont $[1,2]$ consists of a network of interacting bacterial, archaeal, viral, fungal, protistan (i.e., Symbiodinium dinoflagellates), and coral cells (reviewed within [3]). While Symbiodinium are critical for providing carbon to the coral [4], bacteria and archaea may also play important roles by enhancing nutrient cycling $[5,6]$, inducing coral settlement [7], and preventing coral diseases via production of antibiotic compounds [8,9]. The roles that bacteria and archaea may play in coral health and functioning have encouraged comprehensive investigations into the taxonomic identities and functional genes of microorganisms associated with globally distributed coral species. These studies have described widespread as well as health-related and ecologically important coral-microbial associations [10-12].

Cultivation-independent methods coupled with nextgeneration sequencing technologies have been increasingly used to examine coral-microbial associations [11-15]. These methods rely on the extraction of nucleic acids (DNA and RNA) from environmental samples and are advantageous because they allow for the study of hostmicrobe interactions that are difficult to examine using cultivation-dependent methods (reviewed within [3]). The overall utility of these cultivation-independent approaches relies on the comprehensiveness of the extraction of nucleic acids from coral biomass. DNA extraction begins with a series of steps designed to rupture cells using chemical, enzymatic, physical, or mechanical means [16]. Investigators seeking to understand coral-associated microorganisms need to strive for representative lysis of morphologically diverse prokaryotic cells embedded within coral tissue $[3,13,15,17]$ and elution of high-quality nucleic acids.

DNA extraction from coral biomass for investigation of associated bacteria and archaea is particularly subject to technical challenges and potential biases. Coral tissue is rife with polymerase chain reaction (PCR) inhibitors $[14,16$, $18,19]$, including humic acids and $\mathrm{Ca}^{2+}$ ions from the residual coral skeleton. Co-elution of these inhibitors during extraction may decrease PCR efficiency and sensitivity, produce false-negative results [19], delay investigations, and limit comparisons by decreasing sample size. In addition, lysis of microbial cells embedded within the matrix of larger eukaryotic coral cells $[3,13,15,17]$ may be particularly difficult to achieve because of the presence of the mesoglea, a supportive tissue layer comprised of strong collagen fibers that is sandwiched between the epidermal and gastrodermal coral tissue layers [20]. Moreover, lysis affinity for cells of a certain size or structure during sample homogenization could bias interpretation of microbial community composition from sequence-based data [21-23].

Differential lysis of cells during the extraction process may also compound biases associated with PCR amplification.
For example, lysis methods with affinities for disrupting coral cells over microbial cells may increase the amount of eukaryotic DNA within the extract, therefore diluting the concentration of microbial relative to eukaryotic DNA. This swamping effect may reduce amplification of microbial DNA during PCR and decrease the overall efficiency of the reaction [24, 25]. In addition, nonspecific amplification of more abundant chloroplast- and mitochondria-derived DNA from the eukaryotic cells by certain primers $[25,26]$ may distort prokaryotic community structure and lead to exclusion of microbial groups found naturally associated with the coral [27].

Commercial DNA extraction kits offer high-throughput and standardized protocols for streamlined sample processing. As such, using these kits minimizes technical variation and enables researchers to make meaningful comparisons between studies. In particular, kits designed by $\mathrm{MO} \mathrm{BIO}$ Laboratories, Inc., have been commonly used to extract DNA from coral biomass for downstream analysis [13, 14, 28-37]. However, as described above, not all DNA extracts from coral biomass are amenable to PCR amplification and this may be intensified for particular coral species. Several studies have reported these methodological issues $[18,35$, 38 ], and a few attempts have been made to optimize coral DNA extraction $[28,36,37,39,40]$. To date, no large-scale studies have evaluated both the utility of and potential biases associated with different DNA extraction treatments for extraction of DNA from disparate coral species.

In response, we conducted a two-phase experiment in order to (1) propose a comprehensive and efficient method for extraction of microbial DNA from coral tissue and (2) assess if DNA extraction treatment influences microbial community composition. Four commercial DNA extraction kits and protocols supplied by MO BIO Laboratories, Inc. PowerSoil $^{\odot}$, PowerPlant ${ }^{\odot}$ Pro, PowerBiofilm ${ }^{\odot}$, and UltraClean ${ }^{\circledR}$ Tissue \& Cells DNA Isolation Kits) were used to extract DNA from seven different coral species during phase I of this study. These kits were selected because they are commonly used to extract DNA from corals [37], and each employs different combinations of chemical, enzymatic, and mechanical disruption to lyse cells. DNA yield and microbial SSU ribosomal RNA (rRNA) gene amplification efficiency were selected as initial screening parameters for phase I extractions because these metrics are inexpensive and quantifiable indicators of DNA extraction success and amplification amenability. The homogenization characteristics of the DNA extraction treatment that yielded the highest average DNA concentrations and amplification efficiencies were further optimized for DNA extraction. These extracts and the second highest performing extracts were then subjected to SSU rRNA gene amplification and sequencing in phase II of this study to investigate potential microbial community bias attributed to the different DNA extraction methods. 


\section{Methods}

\section{Coral collection and processing}

Coral fragments were collected by a scuba diver using a hammer and chisel during field sampling trips to Kapangamarangi Atoll, Micronesia (November 2012), the Florida Keys, USA (May 2013), and Magnetic Bay, Australia (November 2013) (Additional file 1: Table S1). Fragments were stored in a cooler containing ice until they were flash frozen in liquid nitrogen. Fragments were obtained from three representative colonies of the following species: Porites lobata (collected in Micronesia), Pocillopora verrucosa (Micronesia), Acropora humilis (Australia), Orbicella faveolata, Montastraea cavernosa, Orbicella annularis, and Diploria strigosa (Florida Keys). Fragments were shipped back to Woods Hole Oceanographic Institution and stored at $-80{ }^{\circ} \mathrm{C}$ until they were processed.

Using an airbrush, an aerosolized jet of autoclaved $1 \times$ phosphate-buffered saline (PBS) was directed at freshly thawed coral fragments. This method physically separated the coral mucus and tissue from the skeleton and suspended the cellular material in a slurry. The slurry was homogenized and centrifuged at $4{ }^{\circ} \mathrm{C}$ for $20 \mathrm{~min}$ (5000 rpm) to form pellets comprised of coral tissue and mucus. The PBS supernatant was removed, and the tissue was evenly divided into smaller sections using an ethanolsterilized razor. To ensure that differing DNA yields were solely attributed to the lysis efficiency of the extraction treatments, the amount of biomass entering each extraction was standardized for all samples (38.7 $\pm 9.2 \mathrm{mg})$. Subsampled biomass fractions were stored in separate tubes and frozen at $-80{ }^{\circ} \mathrm{C}$ until they were extracted.

\section{Phase I: DNA extractions}

DNA was extracted from subsampled coral biomass using the PowerSoil $^{\oplus}$ (cat \# 12888), PowerPlant ${ }^{\oplus}$ Pro (cat \# 13400), PowerBiofilm ${ }^{\circ}$ (cat \# 24000), and UltraClean ${ }^{\odot}$ Tissue \& Cells (cat \# 12334) DNA Isolation kits following the manufacturer's protocols ( $\mathrm{MO} \mathrm{BIO}$ Laboratories, Inc.) (Fig. 1, Table 1). In this study, the treatments are referred to by their abbreviations: PowerSoil $^{\circledR}$ (PS), PowerPlant ${ }^{\bullet}$ Pro (PP), PowerBiofilm ${ }^{\odot}$ (PB), and UltraClean ${ }^{\odot}$ Tissue \& Cells (UC). In addition, manipulations to the mechanical lysis conditions for the UC extraction were made, resulting in three permutations: Vortex Garnet (VG), Powerlyzer Glass (PG), and Vortex Glass (VGl) (Table 1). The optional proteinase-K digestion step $\left(15 \mu \mathrm{l} ; 20 \mathrm{mg} / \mathrm{mL}\right.$ at $60{ }^{\circ} \mathrm{C}$ for $\left.30 \mathrm{~min}\right)$ was implemented for all UC permutations. Samples were homogenized for 15 min using a vortex adaptor unless otherwise specified. Genomic DNA concentrations were assessed using the dsDNA High Sensitivity Qubit 2.0 fluorometric assay (Life Technologies). After this study was conducted, MO BIO Laboratories merged with Qiagen and announced

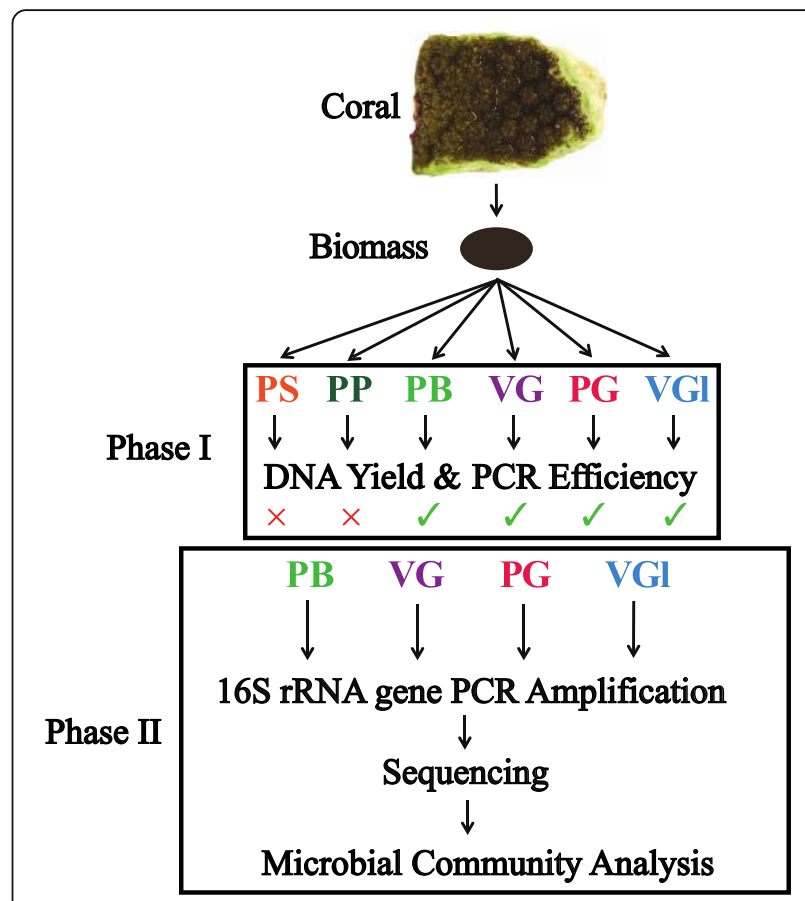

Fig. 1 Overview of experimental design. During phase I, DNA extraction treatments were performed on subdivided tissue, with efficiency of SSU gene amplification assessed using gel screening of PCR products. The green check mark and red $X$ indicate that amplicons from the treatment were and were not chosen for sequencing, respectively.

During phase II, well-performing PB, VG, PG, and VGl extracts were amplified and sequenced for microbial community analysis. PS PowerSoil, PP PowerPlant Pro, PB PowerBiofilm, VG UC Vortex Garnet, PG UC Powerlyzer Glass, VGI UC Vortex Glass

plans to rebrand/discontinue some of their products as of January 1, 2017. To ease in this transition, we have provided the original and new names for the kits used in this study: PS is the DNeasy PowerSoil kit, PP is the DNeasy PowerPlant Pro kit, and PB is the DNeasy PowerBiofilm kit. The UC kit has been discontinued.

DNA template was screened for PCR efficiency using the barcoded primer pair 515F and 806RB [41, 42]. PCR efficiency was determined for each species $\mathrm{X}$ treatment pairing as the normalized percentage of successfully amplified amplicons of the correct size (292 bp) out of all the extracts subjected to PCR. To assess PCR effi-

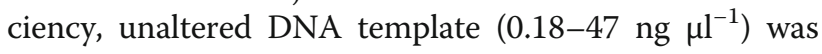
amplified in $25 \mu \mathrm{l}$ reactions containing 1.25 units of GoTaq $^{\odot}$ Flexi DNA Polymerase (Promega), $5 \times$ Colorless GoTaq ${ }^{\bullet}$ Flexi Buffer, $2.5 \mathrm{mM} \mathrm{MgCl}_{2}, 200 \mu \mathrm{M}$ dNTP mix, and $200 \mathrm{nM}$ of each barcoded primer in a thermocycler (Bio-Rad Laboratories). The following PCR reaction conditions were used: $95{ }^{\circ} \mathrm{C}$ for $2 \mathrm{~min}$, followed by 40 cycles of $95{ }^{\circ} \mathrm{C}$ for $20 \mathrm{~s}, 55^{\circ} \mathrm{C}$ for $15 \mathrm{~s}$, and $72{ }^{\circ} \mathrm{C}$ for $5 \mathrm{~min}$, concluding with an extension step of $72{ }^{\circ} \mathrm{C}$ for $10 \mathrm{~min}$. PCR products were visually screened electrophoretically for quality using a 1\% agarose and tris-borate-EDTA gel 
Table 1 Comparison of DNA treatment extraction characteristics

\begin{tabular}{|c|c|c|c|c|c|c|}
\hline MO BIO extraction characteristics & PS & PP & PB & VG & $P G$ & VGl \\
\hline Bead diameter $(\mathrm{mm})$ & 0.7 & 2.38 & $0.1,0.5,2.4^{a}$ & 0.7 & 0.1 & 0.1 \\
\hline Bead type & Garnet & Metal & Glass, Ceramic & Garnet & Glass & Glass \\
\hline Homogenization method & Vortex & Vortex & Vortex & Vortex & Powerlyzer & Vortex \\
\hline Homogenization duration & $15 \mathrm{~min}$ & 15 min & $15 \mathrm{~min}$ & $15 \mathrm{~min}$ & $45 \mathrm{~s}$ & $15 \min$ \\
\hline Surfactant & $<5 \%$ & $<5 \%$ & $x$ & $x$ & $x$ & $x$ \\
\hline Protein precipitant & $20-40 \%$ & $10-20 \%$ & $10-15 \%$ & $x$ & $x$ & $x$ \\
\hline Guanidine thiocyanate & $x$ & $<3 \%$ & $<3 \%, 60-80 \%$ & $x$ & $x$ & $x$ \\
\hline Inhibitor removal & $<10 \%$ & $<5 \%$ & $<10 \%$ & $x$ & $x$ & $x$ \\
\hline Proteinase $\mathrm{K}$ & $x$ & $x$ & $x$ & $1-5 \%$ & $1-5 \%$ & $1-5 \%$ \\
\hline RNase & $x$ & $25 \%$ & $x$ & $x$ & $x$ & $x$ \\
\hline Phenolic separation solution & $x$ & $5-15 \%$ & $x$ & $x$ & $x$ & $x$ \\
\hline
\end{tabular}

$X$ indicates that the parameter was not included

PS PowerSoil, PP PowerPlant Pro, PB PowerBiofilm, VG UC Vortex Garnet, PG UC Powerlyzer Glass, VGI UC Vortex Glass

${ }^{\mathrm{a} P B}$ kit uses 0.1 - and $0.5-\mathrm{mm}$ glass beads and $2.4-\mathrm{mm}$ ceramic beads

illuminated with ultraviolet light with the Hyperladder 50 bp DNA ladder (5 $\mathrm{ng} \mathrm{Hl}^{-1}$ ) (Bioline). Positive amplification for each tested extract was denoted by the presence of a 292-bp-sized band.

\section{Mechanical lysis modifications}

The extraction treatment that yielded extracts with the highest PCR efficiency for all coral colonies and species (UC) was selected to further examine if differences in bead type, homogenization method, and homogenization duration resulted in intra-treatment extraction biases (Fig. 1, Table 1). The garnet beads provided with the UC kit were replaced with 0.1 -mm glass beads (cat \# 13118, MO BIO Laboratories, Inc.) (VGl). For the second modification, a PowerLyzer 24 bench-top bead-based homogenizer (MO BIO Laboratories, Inc., cat \# 13155) was used to homogenize the tissue instead of the vortex adaptor, and garnet beads were replaced with $0.1-\mathrm{mm}$ glass beads (PG). Samples were homogenized with the Powerlyzer for $45 \mathrm{~s}$ at $3500 \mathrm{rpm}$. DNA was not extracted from 3 of the 22 colonies (2 P. verrucosa and 1 A. humilis) using the VGl treatment because of limited biomass. DNA concentrations were quantified, and PCR efficiency was assessed using the methods outlined above.

\section{Phase II: library preparation and sequencing}

Amplicons obtained from the PB, VG, PG, and VGl extractions were selected for sequencing based on overall DNA yield and PCR efficiency (Table 2). In addition, two positive DNA controls obtained from Escherichia coli (Promega) and the Human Microbiome Project mock community DNA (BEI Resources, cat \# HM-276D) and a negative control (U.V. sterilized DNA-free water) were amplified, barcoded, and included in the library pool. As an extra assessment of barcode reproducibility, each $O$. annularis extract was assigned two unique barcodes, amplified in separate reactions, and sequenced.

DNA template was amplified with the same V4 primer set using similar PCR reaction conditions to those described above, but with the number of cycles reduced to 35. Amplicons were purified using gel purification (MinElute PCR Purification Kit, Qiagen) so that only PCR products matching the approximate size of the V4 SSU rRNA gene amplicon were included in the final library pool. Samples were prepared for sequencing using the methods previously outlined by Apprill and colleagues [41]. The amplicon pool was shipped to the University of Illinois W. M. Keck Center for Comparative and Functional Genomics and sequenced using $2 \times 250$ bp MiSeq (Illumina) [41, 42].

\section{Sequence processing}

Mothur software [42] (v.1.33.3) was used to combine the de-multiplexed paired reads $(8,344,281$ contigs $)$ and remove longer sequences ( $>275 \mathrm{bp}$ ) and sequences containing ambiguous base pairs. The expected length of the amplified region with the PCR-specific primers removed was $254 \mathrm{bp}$. A subset of longer sequences with read lengths exceeding $275 \mathrm{bp}$ were queried using the NCBI BLASTN 2.3.0 program [43, 44] to evaluate the taxonomic affiliation of these sequences. The remaining sequences were classified using the SILVA SSU Ref database [45] (v. 119), and sequences corresponding to Eukaryota, mitochondria, and "unknown" lineages were discarded (2802 sequences). Chloroplast sequences were retained to assess if more chloroplast sequences were associated with a particular DNA extraction treatment. The UCHIME algorithm [46] was used to identify and remove chimeric sequences $(13,724$ sequences total). Sequences were not subsampled $[47,48]$. 
Table 2 Summary of DNA extraction yield and PCR efficiency for extractions performed in phase I, with samples selected for phase II bolded

\begin{tabular}{|c|c|c|}
\hline $\begin{array}{l}\text { Treatment } \times \text { species } \\
\text { (number of samples) }\end{array}$ & $\begin{array}{l}\text { Average DNA yield } \\
\text { (S.D.) }\left(n g \mu^{-1}\right)^{\mathrm{a}}\end{array}$ & PCR efficiency \\
\hline PS $\times$ P. lobata (3) & $4.38(2.60)^{b, c}$ & 1 \\
\hline $\mathrm{PP} \times$ P. lobata (3) & $3.73(1.92)^{b, c}$ & 0.67 \\
\hline $\mathrm{PB} \times$ P. lobata $(3)$ & $3.27(2.86)^{b, c}$ & 1 \\
\hline VGI $\times$ P. lobata (3) & $0.74(0.36)^{c}$ & 1 \\
\hline PG $\times$ P. lobata (3) & $0.40(0.06)^{c}$ & 0.33 \\
\hline VG $\times P$. lobata (3) & $10.31(5.69)^{b}$ & 0.67 \\
\hline PS $\times P$. verrucosa $(3)$ & $7.35(10.71)$ & 0.67 \\
\hline $\mathrm{PP} \times \mathrm{P}$. verrucosa $(3)$ & $7.96(7.81)$ & 0 \\
\hline $\mathrm{PB} \times P$. verrucosa $(3)$ & $27.21(23.58)$ & 0.67 \\
\hline VGI $\times P$. verrucosa $(1)$ & 4.14 & 1 \\
\hline $\mathrm{PG} \times P$. verrucosa $(3)$ & $6.06(3.56)$ & 1 \\
\hline VG $\times P$. verrucosa $(3)$ & $12.17(6.83)$ & 1 \\
\hline PS $\times$ A. humilis (3) & $18.11(25.20)$ & 0 \\
\hline $\mathrm{PP} \times$ A. humilis (3) & $7.75(11.33)$ & 0.33 \\
\hline $\mathrm{PB} \times A$. humilis (3) & $38.20(11.70)$ & 1 \\
\hline VGI $\times A$. humilis (2) & $9.46(5.43)$ & 1 \\
\hline PG $\times$ A. humilis (3) & $5.49(4.56)$ & 1 \\
\hline VG $\times A$. humilis (3) & $29.33(3.31)$ & 1 \\
\hline PS $\times 0$. faveolata (4) & $6.51(2.95)$ & 0.75 \\
\hline $\mathrm{PP} \times 0$. faveolata (4) & $2.24(1.46)$ & 0 \\
\hline $\mathrm{PB} \times 0$. faveolata $(4)$ & $8.05(8.08)$ & 1 \\
\hline VGI × O. faveolata (4) & $8.24(7.69)$ & 1 \\
\hline PG $\times$ O. faveolata $(4)$ & $7.47(9.79)$ & 1 \\
\hline VG $\times$ O. faveolata (4) & $12.19(13.27)$ & 1 \\
\hline PS $\times$ M. cavernosa $(3)$ & $2.73(2.10)$ & 0.33 \\
\hline $\mathrm{PP} \times \mathrm{M}$. cavernosa $(3)$ & $1.31(0.42)$ & 0 \\
\hline $\mathrm{PB} \times M$. cavernosa $(3)$ & $1.62(1.06)$ & 0.67 \\
\hline VGI $\times$ M. cavernosa $(3)$ & $0.67(0.36)$ & 0.67 \\
\hline PG $\times M$. cavernosa $(3)$ & $1.59(1.58)$ & 1 \\
\hline VG $\times$ M. cavernosa $(3)$ & $1.79(1.73)$ & 0.33 \\
\hline PS $\times 0$. annularis (3) & $7.23(7.54)$ & 0 \\
\hline $\mathrm{PP} \times 0$. annularis $(3)$ & $1.97(1.18)$ & 0 \\
\hline $\mathrm{PB} \times 0$. annularis $(3)$ & $9.92(7.31)$ & 1 \\
\hline VGI × O. annularis (3) & $1.63(1.08)$ & 1 \\
\hline PG $\times$ O. annularis $(3)$ & $1.47(1.78)$ & 1 \\
\hline VG $\times 0$. annularis $(3)$ & $11.47(13.35)$ & 1 \\
\hline PS $\times$ D. strigosa $(3)$ & $2.28(2.25)$ & 0.33 \\
\hline $\mathrm{PP} \times$ D. strigosa $(3)$ & $1.14(0.29)$ & 0 \\
\hline $\mathrm{PB} \times$ D. strigosa $(3)$ & $0.96(0.62)$ & 0.33 \\
\hline
\end{tabular}

Table 2 Summary of DNA extraction yield and PCR efficiency for extractions performed in phase I, with samples selected for phase II bolded (Continued)

\begin{tabular}{|c|c|c|}
\hline VGI $\times$ D. strigosa $(3)$ & $0.24(0.16)$ & 0.33 \\
\hline PG $\times$ D. strigosa $(3)$ & $0.33(0.14)$ & 0.33 \\
\hline VG $\times$ D. strigosa (3) & $0.98(0.41)$ & 1 \\
\hline
\end{tabular}

The sequences were grouped into nodes using the Minimum Entropy Decomposition (MED) algorithm [49]. These MED nodes are analogous to operational taxonomic units (OTUs) and resolve biologically meaningful and distinct groups that can be separated by $<1 \%$ sequence disparities $[49,50]$. Taxonomy was assigned to MED nodes using the classify.seqs command in mothur [42] and the SILVA database (v. 119) [45]. Sequences belonging to "unclassified" MED nodes were re-aligned using the SINA alignment service [51] (v. 1.2.11) and imported into ARB [52] using the SILVA v. 123 database where phylogenetic comparisons were made using neighbor joining algorithms to resolve "unclassified" taxonomy. The mock community and positive control DNA sample yielded the expected communities, replicate barcoded samples produced repeatable results, and the negative control samples did not pass quality control; these samples were then excluded from the analysis.

\section{Statistical analysis}

DNA concentrations were tested for normality using the Shapiro-Wilk test. Concentrations were then subjected to one-way analysis of variance (ANOVA) or Friedman repeated measures analysis of variance (FRMANOVA) on ranks tests, if data failed the Shapiro-Wilk test, to assess if there were significant differences in mean DNA concentrations between coral species or DNA extraction methods. When appropriate, Tukey's, Holm-Sidak, or Dunn's method post hoc tests were used to determine significantly different groups. $p$ values $\leq 0.05$ were accepted as being statistically significant. The above statistical tests were conducted using SigmaPlot software (v. 13).

Primer (v.7.0.9, Primer- E Ltd.) was used for a majority of the microbial community visualization and alpha diversity analysis. MED richness was calculated using the average number of unique MED nodes detected for each species $\times$ treatment grouping. MED species evenness was determined using the averaged Pielou's evenness index ( $\left.\mathrm{J}^{\prime}\right)$. Bray-Curtis distances were calculated from normalized, square-root transformed sequence data and used to conduct non-metric multidimensional scaling (nMDS) and nested two- and one-way analysis of similarity (ANOSIM) tests. Presence/absence heat maps 
of MED nodes detected from $O$. faveolata, $O$. annularis, and $A$. humilis associated amplicons were created using the phyloseq [53] R package and a custom script [54] that was modified for this study. These heat maps were generated using distinct MED nodes that comprised 50\% of all the reads obtained for each sample and thus represent the most dominant groups found within each colony. Frequency of MED node detection was determined for each treatment (and referred to as the top 50\% MED coverage percentage), and the percentage of detection agreement between pairwise treatments within each colony was assessed. One-tailed $t$ tests were used to reveal significantly different MED node detection between treatments and were conducted using SigmaPlot.

\section{Results}

\section{Phase I: DNA yield and PCR efficiency}

DNA concentrations varied among the extraction treatments (PS, PP, PB, VG, PG, and VGl) with PB yielding the highest average concentration of $12.53 \pm 15.73 \mathrm{ng} \mathrm{ll}^{-1}$ (Fig. 2, Table 2) among all seven coral species. DNA concentrations obtained using the PB and VG treatments had wider distributions than the other treatments, ranging from 0.22 to 46.40 and 0.18 to $32.80 \mathrm{ng}^{-1} \mathrm{l}^{-1}$, respectively. Overall DNA yields from PG and VGl treatments were significantly lower than yields from the PB, VG, and PS treatments (Fig. 2, FRMANOVA, $\mathrm{df}=5, p<0.001$; Tukey's test, $p<0.05)$. Assessment of DNA yields by coral species revealed that PG and VGl $P$. lobata extracts had significantly lower DNA yields than VG extracts (Table 2; one-

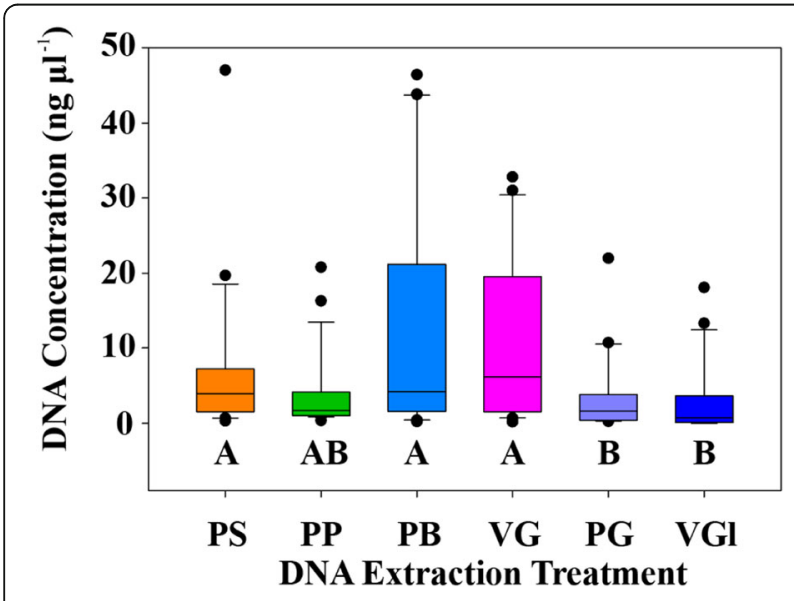

Fig. 2 Boxplots of total DNA concentrations grouped by treatment ( $n=19-22$ individual extractions per treatment). $A$ and $B$ letters differentiate significantly different groups (Tukey's test $p<0.05$ ). Medians are indicated by the solid black lines, and the 25 and $75 \%$ quartiles are represented by the lower and upper bounds of the box. Outliers are indicated as black circles and represent samples falling outside the 10 and $90 \%$ quartiles. PS PowerSoil, PP PowerPlant Pro, PB PowerBiofilm, VG UC Vortex Garnet, PG UC Powerlyzer Glass, VGI UC Vortex Glass way FRMANOVA; Holm-Sidak method, $p<0.05)$, but this trend was not observed for the other species.

Gel screening was used to assess the efficiency of SSU rRNA gene amplification; VG and VGl extracts had the highest species coverage and PCR efficiency, defined as the percentage of extracts yielding visible and appropriately sized ( 292 bp) bands in the gel (Table 2, Additional file 1: Table S2). Similarly, efficiencies of PB and PG extracts were moderately high (amplifying for $82 \%$ of all of the samples) and comparable with the VG and VGl extracts (Additional file 1: Table S2). In contrast, efficiencies of PS and PP extracts were poor with the PS extracts amplifying for $45 \%$ of samples and PP extracts only amplifying for $14 \%$ of all samples (Additional file 1: Table S2). Nonspecific priming, indicated by the presence of multiple larger or smaller bands, was evident in a majority of the samples regardless of treatment. These nonspecific bands $(\sim 200$ and $\sim 450 \mathrm{bp}$ ) were prominent in 58 and $52 \%$ of the PCR products derived from PB and VG extracts, respectively.

During library preparation, $26 \%$ of the samples failed to amplify using the designated temperature cycling conditions for the primers and 35 PCR cycles. Some of these samples may have amplified at a higher number of PCR cycles or with dilution of the DNA template, but PCR optimization for every extract extended beyond the goals of this experiment. DNA extracts obtained from $D$. strigosa had the highest PCR failure rate of $75 \%$ in stark contrast to extracts from O. faveolata and O. annularis that had 100\% PCR amplification success.

\section{Phase II: sequencing results}

Amplicons obtained from the PB, VG, PG, and VGl treatments were prepared for sequencing of SSU rRNA genes in order to thoroughly assess the impact of DNA extraction treatment on microbial community composition. These amplicons were generated from 65 discrete coral colony and extraction treatment combinations representing all seven coral species. Regardless of treatment, there was a statistically significant disparity in the number of quality-filtered microbial sequences obtained from $P$. lobata and $P$. verrucosa corals in comparison to the other species (Fig. 3). A majority of the reads obtained from $P$. lobata and $P$. verrucosa amplicons were too long and therefore were eliminated during preliminary qualityfiltering. A subset of these longer reads corresponded to mitochondrial coral DNA sequences (NCBI accession numbers for top identities: JQ911534.1, $e$ value $=1 \mathrm{e}-102$; EF597054.1, $e$ value $=1 \mathrm{e}-102 ;$ LN864762.1 $e$ value $=$ 6e-101). P. lobata and P. verrucosa amplicons contributed a smaller proportion of sequences to the dataset in comparison to other species because of these disparities. In addition, all $M$. cavernosa $\mathrm{PB}$ extracts and $D$. strigosa 


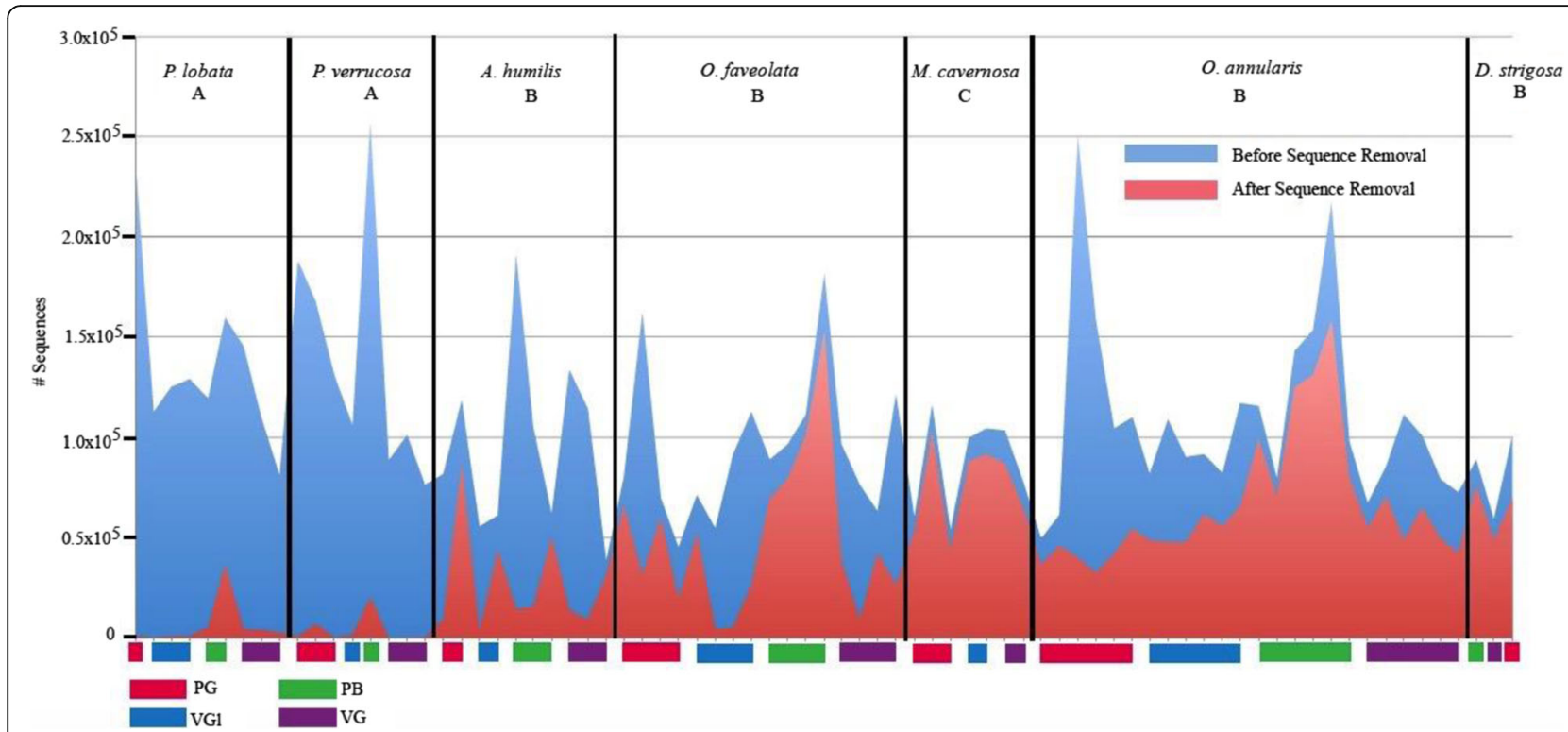

Fig. 3 Number of sequences before and after quality filtering and removal of low-quality sequences. Samples are grouped by DNA extraction treatment nested within coral species. Different letters ( $A, B$, and $C$ ) denote statistically significant differences between species (one-tailed $t$ test or Mann-Whitney ranked sums test, $p<0.05)$. PG UC Powerlyzer Glass, VGI UC Vortex Glass, PB PowerBiofilm, VG UC Vortex Garnet

VGl extracts had very low reads from the outset and were removed from analysis during quality filtering.

Microbial community analysis of the SSU rRNA gene sequences demonstrated that, on a large-scale, microbial community composition was significantly influenced by coral species and not DNA extraction treatment (Fig. 4a, two-way nested ANOSIM, seven coral species (B) nested within four extraction treatments (A), for $\mathrm{A}: R=-0.059$, $p=0.798$, for $\mathrm{B}: R=0.684, p=0.001)$. Independent analysis of $O$. faveolata, $O$. annularis, and A. humilis amplicons (Fig. 4b-d) revealed that microbial community composition was regulated by the coral colony used in the extraction (two-way nested ANOSIM, coral colonies (B) nested within four extraction treatments (A), for A: $R=0.013, p=0.267$, for $\mathrm{B}: R=0.9, p=0.001$ ) rather than DNA extraction treatment. Additional testing within each coral species confirmed this observation that DNA extraction method did not significantly influence

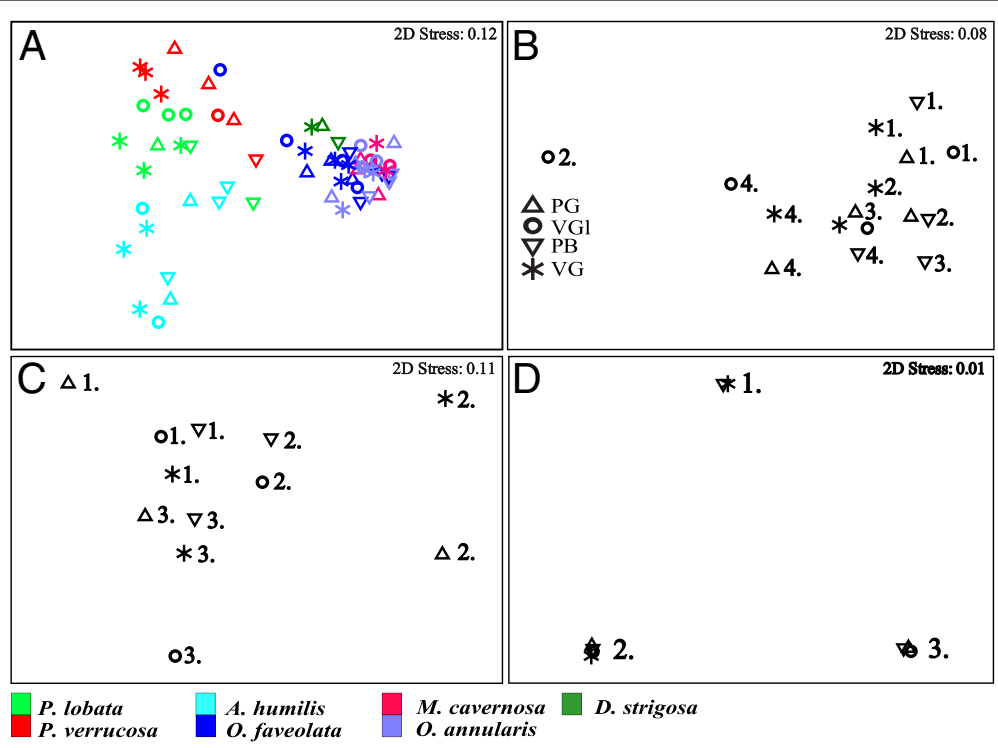

Fig. 4 nMDS ordination of SSU rRNA gene sequences recovered from the different DNA extraction treatments and compared using Bray-Curtis distances for a all species, $\mathbf{b} O$. faveolata, $\mathbf{c} O$. annularis, and $\mathbf{d} A$. humilis. In $\mathbf{a}$, species groupings are designated by colors. In $\mathbf{b}-\mathbf{d}$, samples from the same coral colony are designated by number 
microbial community composition (one-way ANOSIM, $R=0.022, p=0.364$, O. faveolata $R=0.065, p=0.239, O$. annularis; $R=-0.044, p=0.512$, A. humilis). Non-metric multidimensional scaling analysis further supported this result, demonstrating that the same coral colonies clustered together regardless of the extraction treatment (Fig. 4b-d). In-depth microbial community analysis was not possible for all species and treatments because of PCR inhibition and sequence disparities (Table 3).

Overall, no statistically significant differences in MED node richness were detected for a majority of the treatments, with the exception of amplicons from $P$. verrucosa $(\mathrm{df}=4$, one-tailed $t$ test, $p=0.03$ ) and $A$. humilis $(\mathrm{df}=2$, one-way ANOVA, $p=0.023)$ (see Table 3). For $A$.

Table 3 Summary of microbial community analysis conducted during phase II

\begin{tabular}{|c|c|c|c|c|c|c|c|}
\hline Treatment $\times$ species & $n$ & \# reads ${ }^{a}$ & MED richness ${ }^{b}$ & MED evenness $\left(J^{\prime}\right)^{c}$ & $\begin{array}{l}\text { Total community } \\
\text { structure }^{d}\end{array}$ & Detailed analysis & $\begin{array}{l}\text { Top } 50 \% \text { MED } \\
\text { coverage }\end{array}$ \\
\hline $\mathrm{PB} \times$ P. lobata & 2 & $142,167(14,141)$ & $129(35)$ & $0.40(0.13)$ & \multirow{2}{*}{$\begin{array}{l}\text { VGl, PB: } R=0.75 \\
\text { VGI, VG: } R=1 \\
\text { VG, PB: } R=0.5 \\
p=0.001 \text { for all }\end{array}$} & \multirow[t]{4}{*}{ No; low reads } & \multirow[t]{4}{*}{-} \\
\hline VGI $\times$ P. lobata & 3 & $401(161)$ & $86(22)$ & $0.70(0.07)^{d}$ & & & \\
\hline$P G \times P$. lobata & 1 & 641 & 100 & 0.61 & - & & \\
\hline VG $\times$ P. lobata & 3 & $2594(713)$ & $74(16)$ & $0.29(0.08)$ & Tested above & & \\
\hline $\mathrm{PB} \times P$. verrucosa & 1 & 13,153 & 161 & 0.53 & - & \multirow{4}{*}{$\begin{array}{l}\text { No; low reads; low } \\
\text { biological replication }\end{array}$} & \multirow[t]{4}{*}{-} \\
\hline VGI $\times P$. verrucosa & 1 & 603 & 117 & 0.78 & - & & \\
\hline$P G \times P$. verrucosa & 3 & 745 (691) & $105(19)^{d}$ & $0.77(0.16)$ & \multirow[t]{2}{*}{ No differences } & & \\
\hline$V G \times P$. verrucosa & 3 & $152(23)$ & $65(11)$ & $0.85(0.04)$ & & & \\
\hline $\mathrm{PB} \times \mathrm{A}$. humilis & 3 & $22,105(20,156)$ & $131(30)$ & $0.31(0.21)$ & \multirow[t]{4}{*}{ No differences } & \multirow[t]{4}{*}{ Yes } & 0.78 \\
\hline VGI $\times$ A. humilis & 2 & $21,133(27,005)$ & $60(2)^{d}$ & $0.36(0.41)$ & & & 0.67 \\
\hline$P G \times A$. humilis & 2 & $42,241(53,217)$ & $85(2)$ & $0.40(0.45)$ & & & 0.67 \\
\hline VG $\times A$. humilis & 3 & $15,536(11,314)$ & $59(5)^{d}$ & $0.27(0.21)$ & & & 0.7 \\
\hline $\mathrm{PB} \times$ O. faveolata & 4 & $72,587(25,401)$ & $378(71)$ & $0.60(0.16)$ & \multirow[t]{4}{*}{ No differences } & \multirow[t]{4}{*}{ Yes } & 0.84 \\
\hline $\mathrm{VGI} \times 0$. faveolata & 4 & $16,355(18,421)$ & $237(90)$ & $0.56(0.17)$ & & & 0.71 \\
\hline $\mathrm{PG} \times 0$. faveolata & 4 & $28,852(17,895)$ & $392(87)$ & $0.66(0.12)$ & & & 0.77 \\
\hline VG $\times$ O. faveolata & 4 & $18,630(9437)$ & $361(43)$ & $0.61(0.10)$ & & & 0.68 \\
\hline $\mathrm{PB} \times$ M. cavernosa & 0 & $\mathrm{n} / \mathrm{a}$ & $\mathrm{n} / \mathrm{a}$ & $\mathrm{n} / \mathrm{a}$ & $\mathrm{n} / \mathrm{a}$ & \multirow{4}{*}{$\begin{array}{l}\text { No; not all treatments } \\
\text { represented }\end{array}$} & \multirow[t]{4}{*}{-} \\
\hline VGI $\times$ M. cavernosa & 2 & $65,040(3908)$ & $405(22)$ & $0.63(0.12)$ & \multirow[t]{3}{*}{ No differences } & & \\
\hline $\mathrm{PG} \times \mathrm{M}$. cavernosa & 3 & $51,741(26,956)$ & $366(40)$ & $0.57(0.04)$ & & & \\
\hline VG $\times$ M. cavernosa & 2 & $52,055(7028)$ & $355(115)$ & $0.67(0.14)$ & & & \\
\hline $\mathrm{PB} \times 0$. annularis & 3 & $87,777(11,390)$ & $485(60)$ & $0.73(0.09)$ & \multirow[t]{4}{*}{ No differences } & \multirow[t]{4}{*}{ Yes } & 0.87 \\
\hline $\mathrm{VGI} \times 0$. annularis & 3 & $32,681(4358)$ & $357(45)$ & $0.74(0.08)$ & & & 0.77 \\
\hline$P G \times 0$. annularis & 3 & $24,582(4974)$ & $313(130)$ & $0.75(0.15)$ & & & 0.67 \\
\hline$V G \times O$. annularis & 3 & $34,152(8088)$ & $382(123)$ & $0.71(0.16)$ & & & 0.77 \\
\hline $\mathrm{PB} \times \mathrm{D}$. strigosa & 1 & 65,392 & 268 & 0.27 & \multirow[t]{4}{*}{$\mathrm{n} / \mathrm{a}$} & \multirow{4}{*}{$\begin{array}{l}\text { No; not all treatments } \\
\text { represented; low biological } \\
\text { replication }\end{array}$} & \multirow[t]{4}{*}{-} \\
\hline$V G I \times D$. strigosa & 0 & $\mathrm{n} / \mathrm{a}$ & $\mathrm{n} / \mathrm{a}$ & $\mathrm{n} / \mathrm{a}$ & & & \\
\hline$P G \times D$. strigosa & 1 & 60,393 & 211 & 0.23 & & & \\
\hline$V G \times D$. strigosa & 1 & 41,726 & 172 & 0.18 & & & \\
\hline
\end{tabular}

All values are presented as mean (standard deviation (S. D.)) when appropriate. Single values with no S.D. represent samples from treatments with no replicates, and these values were not included in statistical significance testing

$n=$ number of samples included in microbial community analysis after quality-filtering sequences

${ }^{a}$ Average number of reads obtained for that species $\times$ treatment grouping out of the total number of analyzed reads

${ }^{\mathrm{b}}$ Species superscripts within a column indicate significantly different MED richness between treatments $(p<0.05$, one-tailed $t$ test or one-way ANOVA with the Holm-Sidak method post hoc test)

${ }^{c}$ MED evenness values $\left(J^{\prime}\right)$ for each treatment with different superscripts indicate significant differences in species evenness $(p<0.05$, one-way ANOVA with HolmSidak method post hoc test)

${ }^{\mathrm{d} D i f f e r e n c e s ~ i n ~ c o m m u n i t y ~ s t r u c t u r e ~ w e r e ~ f i r s t ~ d e t e r m i n e d ~ u s i n g ~ o n e-w a y ~ A N O S I M ~ g l o b a l ~ t e s t s ~ w i t h i n ~ e a c h ~ c o r a l ~ s p e c i e s ~(~} p<0.05$ is significance threshold). If significant differences were found, pairwise tests were conducted between the different treatments. Species $\times$ treatment combinations with only one sample were excluded in this analysis 
humilis, Holm-Sidak method tests revealed higher MED node richness in PB compared to VG $(p=0.039)$ and VGl $(p=0.041)$ amplicons. Generally, the average number of MED nodes was lower for $P$. lobata, $P$. verrucosa, and $A$. humilis amplicons in comparison to the other species. Furthermore, amplicons generated from the PB treatment were more likely to have the highest MED richness out of the four treatments, with this being the case for five of the seven species (Table 3). MED species evenness (J') tended to be higher in all treatments except the PB treatment (Table 3). Overall, D. strigosa had the lowest evenness whereas $O$. annularis and $P$. verrucosa had the highest evenness.
To tease apart the pattern between MED richness and DNA extraction method on a finer scale, pairwise investigations of differences between treatments were completed using presence/absence analysis of MED nodes for O. faveolata, O. annularis, and A. humilis (Fig. 5). Overall, there was fairly high MED node detection agreement between the sequences generated from different treatments extracted from the same coral colony (average agreement ranged from $72-85 \%)$. Closer inspection revealed that $O$. faveolata $\mathrm{PB}$ sequences had significantly higher MED presence/absence coverage of dominant microbial groups compared to VGl (one-tailed, paired $t$ test, $p=0.013)$ and VG $(p=0.007)$ sequences. Including

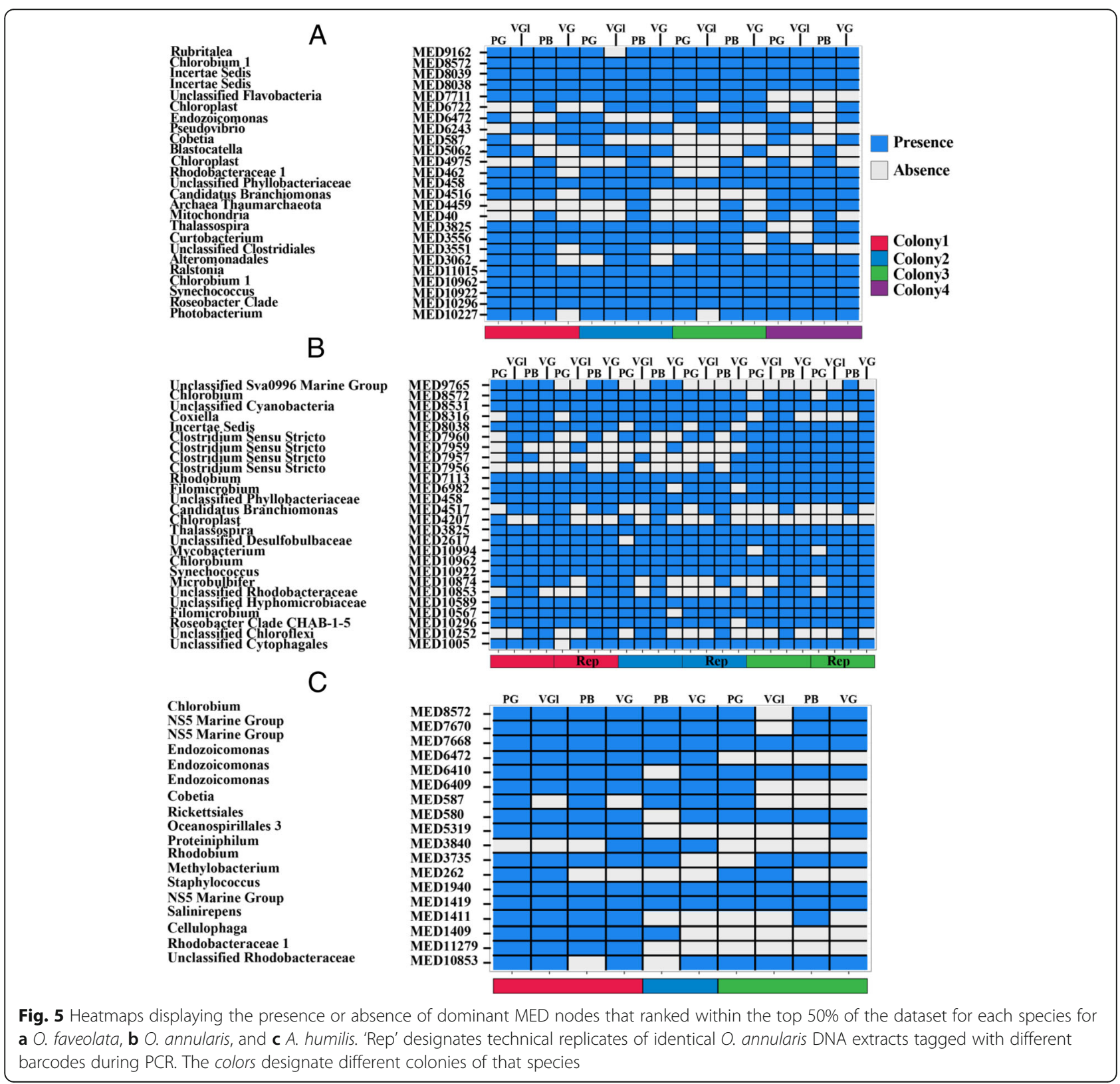


technical replicates, PB sequences from $O$. annularis had significantly higher MED coverage compared to sequences from the PG $\left(p=2.0 \times 10^{-4}\right)$ and VGl $(p=0.019)$ treatments. A significant difference in MED coverage was revealed between PG and VGl amplicons $(p=0.004)$ for $O$. annularis, but this trend was not observed in $O$. faveolata or A. humilis. Sequences generated from O. faveolata PB extracts contained more "Candidatus Branchiomonas" (MED node 4516) and Thaumarchaeota (MED node 4459) reads in comparison to other treatments from this species. Similarly, $\mathrm{Ca}$. Branchiomonas (MED node 4517) was identified in more PB treatment sequences from $O$. annularis compared to the other treatments. MED node presence/absence agreement in $O$. annularis technical replicates was very high with only a few occurrences of disagreement between three technical replicates (9 out of 182 possible disagreements). Statistically significant differences in MED coverage of the dominant groups between treatments were not detected in sequences obtained from A. humilis amplicons, but sequences from the PB treatment had the highest coverage of dominant MED nodes $(78 \%)$ out of all the treatments for this species.

\section{Discussion}

In this study, the PB and all variations of the UC (PG, VGl, VG) treatments were found to be technically suitable and reliable for extraction of microbial DNA from most colonies of $P$. lobata, $P$. verrucosa, A. humilis, $O$. faveolata, O. annularis, and D. strigosa. PCR inhibition during library preparation and significant removal of sequences during quality-filtering prevented highly resolved comparisons for $P$. lobata, $P$. verrucosa, $M$. cavernosa, and $D$. strigosa, demonstrating the importance of including many biological replicates for each species in sequencing-based investigations. Broadly, extraction treatment did not significantly bias microbial community composition, but finer scale investigations for O. faveolata, O. annularis, and A. humilis revealed minor differences in MED coverage and group sensitivity between the UC and PB derived communities.

Generally, all treatments yielded DNA concentrations that fell within the range of previously reported DNA concentrations for corals [36, 37]. While the VG and PB treatments yielded similar DNA concentrations, the PG and VGl treatments yielded extracts with lower DNA concentrations, an observation likely attributed to differences in the duration of mechanical lysis and bead size. In this study, significantly higher DNA yields were obtained from treatments that homogenized samples for 15 min (VG, PB) on a vortex adaptor in comparison to $45 \mathrm{~s}$ (PG) using a powerlyzer and this result aligns with the reported observation that DNA concentration increases with bead-beating duration [55]. Furthermore, larger beads are more likely to lyse eukaryotic coral cells and release more DNA ( 420 Mbp coral genome ${ }^{-1}$ [56]) whereas smaller beads are probably targeting the smaller microbial cells containing less DNA ( 0.9-9.7 Mbp microbial genome $^{-1}$ [57]). In this study, lower concentrations of DNA may have been obtained because the beads were either too large in diameter to effectively disrupt coral and microbial cells (PP) or so small that they could not sufficiently rupture eukaryotic cells (PG, VGl). Lastly, the PB and UC treatments had less sample transfer steps (2) than the PS (4) and PP (3) kits. Minimizing steps during extraction likely helps maintain nucleic acid integrity and may also limit introduction of contaminants, reduce waste, and decrease extraction duration.

The UC (VG, PG, and VGl) and PB treatments yielded extracts that had similar PCR efficiencies. This may be because the UC and PB treatments physically lysed cells using high heat exposure [58]. Using an additional method to achieve cellular lysis may have increased the chance of disrupting cells from a wider variety of microorganisms and the overall concentration of prokaryotic DNA relative to eukaryotic DNA within the extraction. More importantly, the $100 \%$ amplification success of $O$. annularis UC and $\mathrm{PB}$ extracts in this study contrasts with the poor amplification (20-60\%) reported for this species in a recent comparative DNA extraction optimization study using the PS and PP DNA treatments [37] and marks a promising advance in defining a suitable extraction method for this species.

PCR inhibition associated with particular coral species (D. strigosa) or colonies (M. cavernosa) may have arisen due to differences in PCR inhibitor carryover during initial sample processing. For example, we found that the calcium carbonate skeleton of $D$. strigosa colonies fractured more during sample processing in comparison with other species. This likely resulted in co-elution of calcium $\left(\mathrm{Ca}^{2+}\right)$ ions with DNA during the final step of the extraction. Because $\mathrm{Ca}^{2+}$ ions compete with magnesium $\left(\mathrm{Mg}^{2+}\right)$ ions as cofactors for DNA polymerase, higher concentrations of $\mathrm{Ca}^{2+}$ in D. strigosa extracts could have resulted in greater inhibition of DNA polymerase [59, 60]. Baker \& Kellogg [37] also offered this hypothesis to explain differential PCR amplification between coral species and emphasized the importance of using multiple coral species for optimization experiments. For future experiments, it may be appropriate to increase the $\mathrm{Mg}^{2+}$ concentration used during $\mathrm{PCR}$ to overcome this inhibition $[59,60]$.

Unfortunately, neither DNA concentration nor PCR efficiency alone serve as definite indicators of sequence data quality, a concept not demonstrated in past coral DNA optimization studies [36, 37], but supported by previous coral microbiota sequencing studies $[12,61]$ and the disparities between DNA concentration, PCR efficiency, and $P$. lobata and $P$. verrucosa sequence quality 
reported in this study. This observation can possibly be explained by the idea that extracts from $P$. lobata and $P$. verrucosa may be prone to more eukaryotic DNA swamping [37]. Recent efforts for circumventing DNA swamping and nonspecific amplification involve selectively enriching genomic extracts for prokaryotic DNA [24] or designing new PCR primers [62]. Alternatively, as the cost of sequencing declines, deep sequencing of shot-gun metagenomic DNA has increasingly been used to circumvent the issues associated with amplicon-based methods [63]. While this approach may work well for some study systems [64-66], it proves difficult to use for studying complex communities within the coral holobiont; the abundance of coral and Symbiodinium genomic material requires deep sequencing and even size-fractionation may not effectively enrich the target communities of interest $[11,67]$.

Microbial community analysis revealed that most of the variation in microbial community composition corresponded with coral species or colony rather than DNA extraction method. This agrees with the results of a human microbiome study that attributed most of the variation in microbial community composition to different human subjects rather than DNA extraction method [22]. As a whole, this result suggests that the chosen DNA extraction method (either the PowerBiofilm ${ }^{\circ}$ or the different permutations of the UltraClean ${ }^{\circ}$ Tissue and Cells DNA Isolation kit) should not impart significant biases on microbial community composition if the aim of the study is to elucidate large differences in microbial community composition that correspond with changes in coral health, coral species, or other factors. Because many investigations are interested in making these larger comparisons, we recommend that both the PowerBiofilm ${ }^{\circ}$ or the different permutations of the UltraClean ${ }^{\circ}$ Tissue and Cells DNA Isolation kit are suitable for broad investigations of coral microbial dynamics.

This recommendation is verified by the finding that the dominant taxonomic classes of bacteria and archaea recovered in this dataset support the results of other coral microbiota taxonomic surveys. A recent review from Bourne and colleagues [68] identified Gammaproteobacteria, Alphaproteobacteria, Actinobacteria, Bacteroidetes (esp. Flavobacteria), and Cyanobacteria as common coral-associated bacteria, and all these groups were detected in this study. At a finer scale, we detected bacterial genera that have been previously identified as coral associates. For example, in this study, MED nodes identified as Endozoicomonas (class Gammaproteobacteria) were present in all, but two of the samples (varying relative abundances of 0.002-80.02\%). Endozoicomonas bacteria are recognized as potentially important tissue and mucus associates of corals [50, 68, 69], and their genomes suggest functional adaptations for residing with a host [70, 71]. Ralstonia spp. have also been detected in coral microbiota surveys of many different species $[13,28,69]$ and observed within coral-host cells in close proximity to symbiotic dinoflagellates [13]. The functional role of Ralstonia spp. in corals has not been confirmed, but genetic evidence also suggests that they are wellsuited for the symbiotic lifestyle [13]. We detected four distinct MED nodes associated with the Ralstonia genus in 74/77 of our samples, with the highest average relative abundances found in O. faveolata $(2.5+/-9.7 \%)$ and Diploria strigosa $(17+/-30.1 \%)$ corals. This result demonstrates that the DNA extraction methods used in this study may have the capacity to lyse cells located within host-coral cells, thus confirming the use of these DNA extraction methods for studying complex, host-associated microbiomes.

However, if the goal of the investigation is to detect specific or cryptic/rare microorganisms [13], care may need to be taken when choosing the DNA extraction method. This recommendation is supported by the minor, but important distinctions in microbial richness and coverage of top microbial groups between treatments that were detected during pairwise comparisons of the presence/absence of discrete MED nodes by coral colony. For example, nMDS and ANOSIM did not discern the higher MED coverage associated with $\mathrm{PB}$ extracts, but this trend was uncovered during presence/ absence evaluation. Higher MED coverage, including the increased likelihood of detecting MED nodes not detected in sequences from other extractions (e.g., $C a$. Branchiomonas, and Thaumarchaeota), may stem from using a mixture of bead sizes and types during PB DNA extraction. Crowder and colleagues [72] used a mixture of 0.1 - and $2.0-\mathrm{mm}$ beads to extract DNA from ticks and reported that the $2.0-\mathrm{mm}$ beads disrupted the tick exoskeleton, while the $0.1-\mathrm{mm}$ beads disrupted soft tissue and microbial cells. The PB kit also uses a mixture of 0.1 - and $0.5-\mathrm{mm}$ glass beads and larger $2.4-\mathrm{mm}$ ceramic beads to mechanically rupture cells. This bead combination may have facilitated lysis of more recalcitrant coral tissue with the ceramic beads $(2.4 \mathrm{~mm})$ and lysis of soft coral tissue $(0.5 \mathrm{~mm})$ and microbial cells $(0.1 \mathrm{~mm})$ with the glass beads. Using bead mixtures during DNA extraction may be particularly important for studies investigating intracellular symbionts or rare microorganisms. Altogether, careful thought about the scope and expected outcomes of the planned research is needed because this may impact which DNA isolation treatment should be used.

\section{Conclusions}

This study demonstrates that the PowerBiofilm ${ }^{\circ}$ and UltraClean ${ }^{\circ}$ Tissue and Cells (and permutations) DNA Isolation kits are appropriate to use for extraction and amplification 
of microbial DNA from most colonies of $P$. lobata, $P$. verrucosa, A. humilis, O. faveolata, O. annularis, and D. strigosa corals. Subsequent microbial community analysis revealed that at a large-scale, overall microbial community structure was significantly determined by coral species rather than DNA extraction treatment, a result that validates the use of either the PowerBiofilm ${ }^{\circ}$ or UltraClean ${ }^{\circ}$ Tissue and Cells (and permutations) DNA Isolation kits for broad coral microbiota comparisons of globally distributed coral species. On a finer scale, subtle, but potentially important differences in microbial community richness and coverage of top microbial groups were detected, trends that may stem from using different bead mixtures during mechanical lysis of the coral tissue. Based upon these results, we suggest that the PowerBiofilm ${ }^{\circ}$ DNA extraction kit is the most reliable and comprehensive kit to use for small scale cultivation-independent characterization of coral microbiota.

As reliance on sequence data for scientific inquiry grows, acknowledgement of biases introduced to samples via methods is important not only for investigation of error and replication, but also for the detection of ecologically meaningful patterns. Methods vigilance, obtained by conducting dedicated method optimization studies, is a cornerstone for cultivation-independent investigations of microbe-host associations. Understanding the influence of technical bias aids our detection of biologically relevant patterns from sequence data and deepens our understanding of the coral microbiome as well as other complex host environments.

\section{Additional file}

Additional file 1: Table S1. Provides information about the species designation, collection site, collection depth, and colony names for the coral biomass samples used in this study. Table S2. Provides more detailed information about the PCR efficiency of each sample. (DOCX $125 \mathrm{~kb}$ )

\section{Abbreviations}

PB: PowerBiofilm ${ }^{\oplus}$; PG: UltraClean ${ }^{\oplus}$ Tissue \& Cells, PowerLyzer ${ }^{\oplus}$ Homogenizer, Glass Beads; PP: PowerPlant ${ }^{\oplus}$ Pro; PS: PowerSoil ${ }^{\oplus}$; VG: UltraClean ${ }^{\circledR}$ Tissue \& Cells, Vortex Adaptor, Garnet Beads; VGl: UltraClean ${ }^{\circledR}$ Tissue \& Cells, Vortex Adaptor, Glass Beads

\section{Acknowledgements}

We thank Ray Dalio for funding the Micronesian expedition; K. Hughen, M Neave, J. Ossolinski, A. Santoro, C. Smith, and the crew of the MN Alucia for the sampling support; and the Federated States of Micronesia for collection permits FM12-11-03S and FM12-11-05S. In Australia, we acknowledge D. Bourne, M. Neave, and C. Voolstra for the sampling support. Corals were collected within the Florida Keys National Marine Sanctuary with the assistance of A. Santoro under permit FKNMS-2013-038 issued by the NOAA, Office of National Marine Sanctuaries.

\section{Funding}

This project was supported by NSF award OCE-1233612 to AA and NSF GRFP award to LW.

\section{Availability of data and materials}

De-multiplexed raw sequence reads supporting the conclusions of this article were deposited into the Sequence Read Archive (SRA, http://www.ncbi.nlm.nih.gov/sra) under the BioProject accession number PRJNA313192 and BioSample accession numbers SAMN04531900 through SAMN04531977. Information about the study can also be found at the Biological and Chemical Oceanography Data Management Office website (http://lod.bco-dmo.org/id/dataset/662114).

\section{Authors' contributions}

LW, ED, and AA contributed to the study design, data interpretation, and manuscript preparation. LW additionally contributed to the data collection and analysis. All authors read and approved the final manuscript.

\section{Authors' information}

1. Laura Weber is a graduate student within the Massachusetts Institute of Technology-Woods Hole Oceanographic Institution Joint Program in Oceanography/Applied Ocean Science and Engineering, Cambridge, MA 02139; Biology Department, Woods Hole Oceanographic Institution, Woods Hole, MA, USA 02543.

2. Emelia Deforce is a microbial ecologist and Research Scientist in R\&D at MO BIO Laboratories, Carlsbad, CA, USA 92010.

3. Amy Apprill is an Associate Scientist within the Marine Chemistry and Geochemistry Department at Woods Hole Oceanographic Institution, Woods Hole, MA, USA 02543.

\section{Competing interests}

While DNA isolation kits were donated by MO BIO Laboratories, Inc., and ED is an employee of MO BIO Laboratories, Inc., the authors maintain that all data, results, and conclusions drawn from this study are made independent of these factors.

\section{Consent for publication}

Not Applicable.

Ethics approval and consent to participate

Not applicable.

\section{Author details}

${ }^{1}$ Massachusetts Institute of Technology-Woods Hole Oceanographic Institution Joint Program in Oceanography/Applied Ocean Science and Engineering, Cambridge, MA 02139, USA. ${ }^{2}$ Woods Hole Oceanographic Institution, Marine Chemistry and Geochemistry, Woods Hole, MA 02543, USA. ${ }^{3}$ MO BIO Laboratories, Inc., Carlsbad, CA 92010, USA.

Received: 9 September 2016 Accepted: 4 January 2017

Published online: 08 February 2017

References

1. Rohwer F, Seguritan V, Azam F, Knowlton N. Diversity and distribution of coral-associated bacteria. Mar Ecol Prog Ser. 2002;243:1-10. doi:10.3354/ meps243001.

2. Knowlton N, Rohwer F. Multispecies microbial mutualisms on coral reefs: the host as a habitat. Am Nat. 2003;162(4 Suppl):551-62. doi:10.1086/378684.

3. Thompson JR, Rivera HE, Closek CJ, Medina M. Microbes in the coral holobiont: partners through evolution, development, and ecological interactions. Front Cell Infect Microbiol. 2015:4:1-20, doi:10.3389/fcimb.2014.00176.

4. Muscatine L, McCloskey LR, Marian RE. Estimating the daily contribution of carbon from zooxanthellae to coral animal respiration. Limnol Oceanogr. 1981;26:601-11. doi:10.4319//o.1981.26.4.0601.

5. Lesser MP, Mazel CH, Gorbunov MY, Falkowski PG. Discovery of symbiotic nitrogen-fixing cyanobacteria in corals. Science. 2004;305:997-1000. doi:10.1126/science.1099128.

6. Raina J-B, Tapiolas D, Willis BL, Bourne DG. Coral-associated bacteria and their role in the biogeochemical cycling of sulfur. Appl Environ Microb. 2009:75:3492-501. doi:10.1128/AEM.02567-08.

7. Sneed JM, Sharp KH, Ritchie KB, Paul VJ. The chemical cue tetrabromopyrrole from a biofilm bacterium induces settlement of multiple Caribbean corals. Proc Biol Sci. 2014;281. doi:10.1098/rspb.2013.3086 
8. Ritchie KB. Regulation of microbial populations by coral surface mucus and mucus-associated bacteria. Mar Ecol Prog Ser. 2006;322:1-14. doi:10.3354/meps322001.

9. Krediet CJ, Ritchie KB, Alagely A, Teplitski M. Members of native coral microbiota inhibit glycosidases and thwart colonization of coral mucus by an opportunistic pathogen. ISME J. 2013;7:980-90. doi:10.1038/ismej.2012.164.

10. Bourne DG, Garren M, Work TM, Rosenberg E, Smith GW, Harvell CD. Microbial disease and the coral holobiont. Trends Microbiol. 2009;17(12):554-62. doi:10.1016/j.tim.2009.09.004

11. Thurber RV, Willner-Hall D, Rodriguez-Mueller B, Desnues C, Edwards RA, Angly F, Dinsdale E, Kelly L, Rohwer F. Metagenomic analysis of stressed coral holobionts. Environ Microbiol. 2009;11(8):2148-63. doi:10.1111/ j.1462-2920.2009.01935.x.

12. Apprill A, Hughen $K$, Mincer T. Major similarities in the bacterial communities associated with lesioned and healthy Fungiidae corals. Environ Microbiol. 2013;15(7):2063-1072. doi:10.1111/1462-2920.12107.

13. Ainsworth TD, Krause L, Bridge T, Torda G, Raina JB, Zakrzewski M, Gates RD, Padilla-Gamiño JL, Spalding HL, Smith C, Woolsey ES, Bourne DG, Bongaerts $\mathrm{P}$, Hoegh-Guldberg $\mathrm{O}$, Leggat $\mathrm{W}$. The coral core microbiome identifies rare bacterial taxa as ubiquitous endosymbionts. ISME J. 2015;9:2261-74. doi:10.1038/ismej.2015.39. PowerPlant ${ }^{\circledR}$ Pro DNA Isolation Kit.

14. Sunagawa S, DeSantis TZ, Piceno YM, Brodie EL, DeSalvo MK, Voolstra CR, Weil E, Andersen GL, Medina M. Bacterial diversity and white plague disease-associated community changes in the Caribbean coral Montastraea faveolata. ISME J. 2009;3(5):512-21. doi:10.1038/ismej.2008.131. PowerPlant ${ }^{\oplus}$ Pro DNA Isolation Kit.

15. Mouchka ME, Hewson I, Harvell CD. Coral-associated bacterial assemblages: current knowledge and the potential for climate-driven impacts. Integr Comp Biol. 2010;50(4):662-74. doi:10.1093/icb/icq061.

16. Rudi K, Wilson RC, Jakobsen KS, Liu D. Preparation of bacteria samples for direct molecular applications. In: Liu D, editor. Handbook of nucleic acid purification. Boca Raton: CRC Press; 2009. p. 147-68.

17. Apprill A, Marlow HQ, Martindale MQ, Rappe MS. The onset of microbial associations in the coral Pocillopora meandrina. ISME J. 2009;3:685-99. doi:10.1038/ismej.2009.3.

18. Bourne D, Munn C. Diversity of bacteria associated with the coral Pocillopora damicornis from the Great Barrier Reef. Environ Microbiol. 2005;7(8):1162-74. doi:10.1111/j.1462-2920.2005.00793.x.

19. Schrader C, Schielke A, Ellerbroek L, Johne R. PCR inhibitors-occurrence, properties and removal. J App Microbiol. 2012;113(5):1014-26. doi:10.1111/ j.1365-2672.2012.05384.x.

20. Hausman RE, Burnett AL. The mesoglea of hydra. I. Physical and histochemical properties. J Exp Zool. 1969;171:7-13. doi:10.1002/jez.1401710103.

21. Yuan S, Cohen DB, Ravel J, Abdo Z, Forney LJ. Evaluation of methods for the extraction and purification of DNA from the human microbiome. PLoS One. 2012;7(3), e33865. doi:10.1371/journal.pone.0033865.

22. Mackenzie BW, Waite DW, Taylor MW. Evaluating variation in human gut microbiota profiles due to DNA extraction method and inter-subject differences. Front Microbiol. 2015:6:1-11. doi:10.3389/fmicb.2015.00130.

23. Yang Q, Franco CMM, Zhang W. Sponge-associated actinobacterial diversity: validation of the methods of actinobacterial DNA extraction and optimization of 165 rRNA gene amplification. Appl Microbiol Biotechnol. 2015:99:8731-40. doi:10.1007/s00253-015-6875-8.

24. Feehery GR, Yigit E, Oyola SO, Langhorst BW, Schmidt VT, Stewart FJ, Dimalanta ET, Amaral-Zettler LA, Davis T, Quail MA, Pradhan S. A method for selectively enriching microbial DNA from contaminating vertebrate host DNA. PLoS One. 2013;8(10):e76096. doi:10.1371/journal.pone.0076096.

25. Galkiewicz JP, Kellogg CA. Cross-kingdom amplification using bacteriaspecific primers: complications for studies of coral microbial ecology. Appl Environ Microbiol. 2008;74(24):7828-31. doi:10.1128/AEM.01303-08.

26. Klindworth A, Pruesse E, Schweer T, Peplies J, Quast C, Horn M, Glockner FO. Evaluation of general 165 ribosomal RNA gene PCR primers for classical and next-generation sequencing-based diversity studies. Nucleic Acids Res. 2012;41(1):1-11. doi:10.1093/nar/gks808.

27. Sipos R, Székely AJ, Palatinszky M, Révész S, Márialigeti K, Nikolausz M. Effect of primer mismatch, annealing temperature and PCR cycle number on 165 rRNA gene-targeting bacterial community analysis. FEMS Microbiol Ecol. 2007;60(2):341-50. doi:10.1111/j.1574-6941.2007.00283x.

28. Sunagawa S, Woodley CM, Medina M. Threatened corals provide underexplored microbial habitats. PLoS One. 2010;5(3):e9554. doi:10.1371/ journal.pone.0009554. PowerPlant ${ }^{\circledR}$ Pro DNA Isolation Kit.
29. Salerno JL, Reineman DR, Gates RD, Rappé MS. The effect of a sublethal temperature elevation on the structure of bacterial communities associated with the coral Porites compressa. J Mar Biol. 2011:1-9. doi:10.1155/2011/969173 PowerSoil ${ }^{\oplus}$ DNA Isolation Kit.

30. Ceh J, Raina JB, Soo RM, van Keulen M, Bourne DG. Coral-bacterial communities before and after a coral mass spawning event on Ningaloo reef. PLoS One. 2012;7(5):3. doi:10.1371/journal.pone.0036920. PowerPlant ${ }^{\oplus}$ Pro DNA Isolation Kit.

31. Meron D, Rodolfo-Metalpa R, Cunning R, Baker AC, Fine M, Banin E. Changes in coral microbial communities in response to a natural pH gradient. ISME J. 2012;6(9):1775-85. doi:10.1038/ismej.2012.19. PowerSoil ${ }^{\oplus}$ DNA Isolation Kit.

32. Morrow KM, Moss AG, Chadwick NE, Liles MR. Bacterial associates of two Caribbean coral species reveal species-specific distribution and geographic variability. Appl Environ Microbiol. 2012;78(18):6438-49. doi:10.1128/AEM. 01162-12. UltraClean ${ }^{\circledast}$ Microbial DNA Isolation Kit.

33. Webster NS, Negri AP, Flores F, Humphrey C, Soo R, Botte ES, Vogel N, Uthicke S. Near-future ocean acidification causes differences in microbial associations within diverse coral reef taxa. Environ Microbiol Rep. 2013;5(2): 243-51. doi:10.1111/1758-2229.12006. PowerPlant ${ }^{\circledR}$ Pro DNA Isolation Kit.

34. Garcia GD, Gregoracci GB, Santos Ede O, Meirelles PM, Silva GG, Edwards R, Sawabe T, Gotoh K, Nakamura S, lida T, de Moura RL, Thompson FL. Metagenomic analysis of healthy and white plague-affected Mussismilia braziliensis corals. Microb Ecol. 2013;65(4):1076-86. doi:10.1007/ s00248-012-0161-4. PowerSoil $^{\oplus}$ DNA Isolation Kit.

35. Kellogg CA, Piceno YM, Tom LM, DeSantis TZ, Gray MA, Andersen GL. Comparing bacterial community composition of healthy and dark spot-affected Siderastrea siderea in Florida and the Caribbean. PLoS One. 2014;9(10):e108767. doi:10.1371/journal.pone.0108767. PowerPlant ${ }^{\oplus}$ Pro DNA Isolation Kit.

36. Santos HF, Carmo FL, Leite DCA, Jesus HE, De Carvalho Maalouf P, Almeida C, Soriano AU, Altomari D, Suhett L, Vólaro V, Valoni E, Francisco M, Vieira J, Rocha R, Sardinha BL, Mendes LB, João RR, Lacava B, Jesus RF, Sebastian GV, Pessoa A, van Elsas JD, Rezende RP, Pires DO, Duarte G, Castro CB, Rosado AS, Peixoto RS. Comparison of different protocols for the extraction of microbial DNA from reef corals. Braz J Microbiol. 2012;43(2):517-27. doi:10.1590/ S1517-83822012000200012. PowerSoil ${ }^{\oplus}$ DNA Isolation Kit.

37. Baker E, Kellogg C. Composition of three DNA extraction kits to establish maximum yield and quality of coral-associated microbial DNA. U.S. Geological Survey Open-File Report 2014-1066. 2014;doi:10.3133/ofr20141066. (PowerPlant ${ }^{\oplus}$, PowerPlant ${ }^{\oplus}$ Pro, and PowerSoil $^{\oplus}$ DNA Isolation Kit).

38. Vega Thurber R, Burkepile DE, Correa AMS, Thurber AR, Shantz AA, Welsh R, Pritchard C, Rosales S. Macroalgae decrease growth and alter microbial community structure of the reef-building coral, Porites astreoides. PLoS One. 2012;7(9), e44246. doi:10.1371/journal.pone.0044246.

39. Sekar R, Mills DK, Remily ER, Voss JD, Richardson LL. Microbial communities in the surface mucopolysaccharide layer and the black band microbial mat of black band-diseased Siderastrea siderea. Appl Environ Microbiol. 2006;72(9):5963-73. doi:10.1128/AEM.00843-06.

40. Lampert Y, Kelman D, Nitzan Y, Dubinsky Z, Behar A, Hill RT. Phylogenetic diversity of bacteria associated with the mucus of Red Sea corals. FEMS Microbiol Ecol. 2008;64(2):187-98. doi:10.1111/j.1574-6941.2008.00458x.

41. Apprill A, McNally S, Parsons R, Weber L. Minor revision to V4 region SSU rRNA 806R gene primer greatly increases detection of SAR11 bacterioplankton. Aquat Microb Ecol. 2015;75(2):129-37. doi:10.3354/ame01753.

42. Kozich JJ, Westcott SL, Baxter NT, Highlander SK, Schloss PD. Development of a dual-index sequencing strategy and curation pipeline for analyzing amplicon sequence data on the MiSeq Illumina sequencing platform. Appl Environ Microbiol. 2013;79(17):5112-20. doi:10.1128/AEM.01043-13.

43. Zhang Z, Schwartz S, Wagner L, Miller W. A greedy algorithm for aligning DNA sequences. J Comput Biol. 2000;7(1-2):203-14. doi:10.1089/ 10665270050081478

44. Morgulis A, Coulouris G, Raytselia Y, Madden TL, Agarwala R, Schäffer AA. Database indexing for production MegaBLAST searches. Bioinformatics. 2008:24:1757-64. doi:10.1093/bioinformatics/btn32.

45. Quast C, Pruesse E, Yilmaz P, Gerken J, Schweer T, Yarza P, Peplies J, Glockner FO. The SILVA ribosomal RNA gene database project: improved data processing and web-based tools. Nucleic Acids Res. 2013;41(D1):D590-6. doi:10.1093/ nar/gks1219.

46. Edgar RC, Haas BJ, Clemente JC, Quince C, Knight R. UCHIME improves sensitivity and speed of chimera detection. Bioinformatics. 2011:27(16):2194-200. doi:10.1093/bioinformatics/btr381. 
47. de Ca'rcer DA, Denman SE, McSweeney C, Morrison M. Evaluation of subsampling-based normalization strategies for tagged high-throughput sequencing data sets from gut microbiomes. Appl Environ Microbiol. 2011;77(24):8795-8. doi:10.1128/AEM.05491-11.

48. Holmes S, McMurdie PJ. Waste not, want not: why rarefying microbiome data is inadmissible. PLoS Comput Biol. 2014;10(4):e1003531. doi:10.1371/ journal.pcbi.1003531.

49. Eren AM, Maignien L, Sul WJ, Murphy LG, Grim SL, Morrison HG, Sogin ML. Oligotyping: differentiating between closely related microbial taxa using 16S rRNA gene data. Methods Ecol Evol. 2013;4:1111-9. doi:10.1111/ 2041-210X.12114.

50. Neave MJ, Rachmawati R, Xun L, Michell CT, Bourne DG, Apprill A, Voolstra CR. Differential specificity between closely related corals and abundant Endozoicomonas endosymbionts across global scales. ISME J. 2017:11(7):186-200. doi:10.1038/ismej.2016.95.

51. Pruesse E, Peplies J, Glöckner FO. SINA: accurate high-throughput multiple sequence alignment of ribosomal RNA genes. Bioinformatics. 2012;28:1823-9. doi:10.1093/bioinformatics/bts252.

52. Ludwig W, Strunk O, Westram R, Richter L, Meier HY, Buchner A, Lai T, Steppi S, Jobb G, Förster W, Brettske I, Gerber S, Ginhart AW, Gross O, Grumann S, Hermann S, Jost R, König A, Liss T, Lüßmann R, May M, Nonhoff B, Reichel B, Strehlow R, Stamatakis A, Stuckmann N, Vilbig A, Lenke M, Ludwig T, Bode A, Schleifer KH. ARB: a software environment for sequence data. Nucleic Acids Res. 2004;32(4):1363-71. doi:10.1093/nar/gkh293.

53. McMurdie PJ, Holmes S. Phyloseq: an R package for reproducible interactive analysis and graphics of microbiome census data. PLoS One. 2013;8(4):e61217. doi:10.1371/journal.pone.0061217.

54. Neave MJ. MEDecomposition. GitHub repository. https://github.com/ neavemj/globalCoralMicrobiomes. Accessed 15 Nov 2015.

55. Henderson G, Cox F, Kittelmann S, Miri VH, Zethof M, Noel SJ, Waghorn GC, Janssen $\mathrm{PH}$. Effect of DNA extraction methods and sampling techniques on the apparent structure of cow and sheep rumen microbial communities. PLoS One. 2013;8(9), e74787. doi:10.1371/journal.pone.0074787.

56. Shinzato C, Mungpakdee S, Satoh N, Shoguchi E. A genomic approach to coral-dinoflagellate symbiosis: studies of Acropora digitifera and Symbiodinium minutum. Front Microbiol. 2014:5:1-17. doi:10.3389/fmicb.2014.00336.

57. Koonin EV, Wolf YI. Genomics of bacteria and archaea: the emerging dynamic view of the prokaryotic world. Nucleic Acids Res. 2008;36(21):6688-719. doi:10.1093/nar/gkn668.

58. Middelberg APJ. Process-scale disruption of microorganisms. Biotechnol Adv. 1995;13(3):491-551. doi:10.1016/0734-9750(95)02007-P

59. Al-Soud WA, Rådström P. Purification and characterization of PCR-inhibitory components in blood cells purification and characterization of PCRinhibitory components in blood cells. J Clin Microbiol. 2001;39(2):485-93. doi:10.1128/JCM.39.2.485.

60. Bickley J, Short JK, McDowel DG, Parkes HC. Polymerase chain reaction (PCR) detection of Listeria monocytogenes in diluted milk and reversal of PCR inhibition caused by calcium ions. Lett Appl Microbiol. 1996;22(2):153-8. doi:10.1111/j.1472-765X.1996.tb01131.X.

61. Ziegler M, Roik A, Porter A, Zubier K, Mudarris MS, Ormond R, Voolstra CR. Coral microbial community dynamics in response to anthropogenic impacts near a major city in the central Red Sea. Marine Poll Bull. 2016:105(2):629-40.

62. Mori H, Maruyama F, Kato H, Toyoda A, Dozono A, Ohtsubo Y, Nagata Y, Fujiyama A, Tsuda M, Kurokawa K. Design and experimental application of a novel non-degenerate universal primer set that amplifies prokaryotic 165 rRNA genes with a low possibility to amplify eukaryotic rRNA genes. DNA Res. 2013:21(2):217-27. doi:10.1093/dnares/dst052.

63. Poretsky R, Rodriguez-R LM, Luo C, Tsementzi D, Konstantinidis KT. Strengths and limitations of $16 \mathrm{~S}$ rRNA gene amplicon sequencing in revealing temporal microbial community dynamics. PLoS One. 2014;9(4):e93827.

64. Nesme J, Cécillon S, Delmont TO, Monier JM, Vogel TM, Simonet P. Large-scale metagenomic-based study of antibiotic resistance in the environment. Curr Biol. 2014;24(10):1096-100.

65. He S, Ivanova N, Kirton E, Allgaier M, Bergin C, Scheffrahn RH, ... Hugenholtz P. Comparative metagenomic and metatranscriptomic analysis of hindgut paunch microbiota in wood-and dung-feeding higher termites. PloS one. 2013:8(4):e61126

66. Sunagawa S, Coelho LP, Chaffron S, Kultima JR, Labadie K, Salazar G, ... Cornejo-Castillo FM. Structure and function of the global ocean microbiome. Science. 2015;348(6237):1261359
67. Littman R, Willis BL, Bourne DG. Metagenomic analysis of the coral holobiont during a natural bleaching event on the Great Barrier Reef. Environ Microbiol Rep. 2011;3(6):651-60.

68. Bourne DG, Morrow KM, Webster NS. Insights into the coral microbiome: underpinning the health and resilience of reef ecosystems. Annu Rev Microbiol. 2016;70:317-40. doi:10.1146/annurev-micro-102215-095440.

69. Apprill A, Weber LG, Santoro AE. Distinguishing between microbial habitats unravels ecological complexity in coral microbiomes. mSystems. 2016;1(5):e00143-16. doi:10.1128/mSystems.00143-16.

70. Neave M, Mitchell C, Apprill A, Voolstra C. Endozoicomonas genomes reveal functional adaptation and plasticity in bacterial strains symbiotically associated with diverse marine hosts. Sci Rep. 2017;7:40579. doi:10.1038/ srep40579.

71. Neave MJ, Apprill A, Ferrier-Pagès C, Voolstra CR. Diversity and function of prevalent symbiotic marine bacteria in the genus Endozoicomonas. Appl Microbiol Biotechnol. 2016;100(19):8315-24. doi:10.1007/s00253-016-7777-0.

72. Crowder CD, Rounds MA, Phillipson CA, Picuri JM, Matthews HE, Halverson J, Schutzer SE, Ecker DJ, Eshoo MW. Extraction of total nucleic acids from ticks for the detection of bacterial and viral pathogens. J Med Entomol. 2010;47(1):89-94. doi:10.1603/033.047.0112

\section{Submit your next manuscript to BioMed Central and we will help you at every step:}

- We accept pre-submission inquiries

- Our selector tool helps you to find the most relevant journal

- We provide round the clock customer support

- Convenient online submission

- Thorough peer review

- Inclusion in PubMed and all major indexing services

- Maximum visibility for your research

Submit your manuscript at www.biomedcentral.com/submit

) Biomed Central 